\title{
Development of enteric coated sustained release minitablets containing mesalamine
}

\author{
Dayse Fernanda de Souza*, Karin Goebel, Itamar Francisco Andreazza \\ Pharmacy Department, Federal University of Paraná, Curitiba, PR, Brazil
}

\begin{abstract}
The aim of this study was to develop and evaluate a multiparticulate modified release system, composed of minitablets with a sustained release matrix system coated with a $\mathrm{pH}$-dependent release polymer, using mesalamine as a model drug. Polyox ${ }^{\circledR}$ WSR 1105 was the polymer used in the matrix system and Eudragit ${ }^{\circledR}$ L30D55 was used as a pH-dependent polymer. The minitablets (with $20 \%, 30 \%$ or $40 \%$ Polyox $^{\circledR}$ concentration) were prepared by dry granulation, which led to good quality minitablets. The developed minitablets were coated in a fluidized bed at $8 \%$ of the coating level. Dissolution studies were performed in media that simulated the gastrointestinal tract ( $\mathrm{pH} \mathrm{1.4,6.0} \mathrm{and} \mathrm{7.2)} \mathrm{and} \mathrm{showed} \mathrm{that} \mathrm{formulations} \mathrm{with}$ higher Polyox ${ }^{\circledast}$ concentrations were capable of retaining the drug release in $\mathrm{pH}$ 1.4. All formulations prolonged the drug release and presented zero-order kinetic behaviour. The Korsmeyer-Peppas model demonstrated that formulations with $20 \%$ or $30 \%$ of polymer exhibited anomalous transport behaviour, whilst the $40 \%$ sample exhibited super case II model transportation. Dissolution efficiency showed that only the formulations containing $20 \%$ and $40 \%$ polymer could be considered statistically different.
\end{abstract}

Uniterms: Mesalamine/modified release/evaluation. Minitablets coated/modified release/evaluation. Polyethylene oxide/drugs coating. Drugs/modified release.

O presente trabalho teve como objetivo desenvolver e avaliar um sistema multiparticulado de liberação modificada, composto por minicomprimidos com sistema matricial de liberação prolongada revestidos com polímero de liberação $\mathrm{pH}$-dependente, utilizando mesalazina como fármaco modelo. Polyox ${ }^{\circledR}$ WSR 1105 foi o polímero utilizado no sistema matricial e Eudragit ${ }^{\circledR}$ L30D55 foi utilizado como polímero pH-dependente. Os minicomprimidos (com 20\%, 30\% e 40\% de concentração de Polyox ${ }^{\mathbb{R}}$ ) foram preparados por granulação via seca, gerando minicomprimidos de boa qualidade. Os minicomprimidos desenvolvidos foram revestidos em leito fluidizado a $8 \%$ de nível de revestimento. Efetuou-se o estudo de dissolução em meios que simulam o trato gastrointestinal ( $\mathrm{pH}$ 1,4, 6,0 e 7,2) e as formulação contendo maiores concentrações de Polyox ${ }^{\circledR}$ foram capazes de reter a liberação do fármaco em $\mathrm{pH}$ 1,4. Todas as três formulações apresentaram liberação prolongada e comportamento cinético de ordem zero. O modelo de liberação de Korsmeyer-Peppas mostrou que as formulações com 20\% e 30\% de polímero apresentam comportamento de transporte anômalo, enquanto a com $40 \%$, transporte super caso II. A eficiência de dissolução mostrou que somente as formulações com $20 \%$ e $40 \%$ de concentração do polímero foram consideradas estatisticamente diferentes.

Unitermos: Mesalazina/liberação prolongada/avaliação. Minicomprimidos revestidos/liberação prolongada/avaliação. Óxido de polietileno/revestimento de fármacos. Fármacos/liberação modificada.

\section{INTRODUCTION}

Solid dosage forms are the most frequently used for oral administration, and tablets represent the most

*Correspondence: D. F. Souza. Universidade Federal do Paraná, Departamento de Farmácia. Av. Prefeito Lothário Meissner, 632 - Jardim Botânico - 80210170 - Curitiba - PR, Brasil. E-mail: dayse.fer@gmail.com common pharmaceutical form used (Allen, Popovich, Ansel, 2005). Oral dosage forms can be classified into two broad groups: single unit dosage forms, as capsules and tablets, and multiple unit dosage forms, such as granules, pellets and minitablets (Lopes et al., 2006).

Multiparticulate dosage forms present multiple advantages over single unit dosage forms, demonstrated as flexibility during formulation development and 
therapeutic benefits for the patients, including increased bioavailability, reduced risk of systemic toxicity due to dose dumping and reduced risk of local irritation, besides predictable gastric emptying (Kramar, Turk, Vrecer, 2003).

Although the oral dosage form is the most widely accepted route of administration, the gastrointestinal tract presents several barriers to drug delivery (Gupta, Beckert, Price, 2001). In this way, pharmaceutical technology has played a fundamental role in the investigation of systems that efficiently deliver a drug to its site of action (Déo, Andreazza, Possamai, 2011). The use of modified release allows a drug to be delivered at a rate dictated by the needs of the body over the period of treatment (extended release) and also avoids or directs the drug to specific sites, as in delayed release (Nagaraju et al., 2010).

Extended release may be achieved based on modifying drug dissolution by controlling the access of biologic fluid to the drug. This control can be achieved through barrier coating, micro encapsulation, complex formation, ion exchange resins, or by embedding the drug in a slowly eroding or hydrophilic matrix system. In delayed release dosage forms, enteric coating is generally used to protect drugs from the gastric acidic environment (Allen, Popovich, Ansel, 2004).

Minitablets are tablets with a diameter between 2 and $3 \mathrm{~mm}$ (Lennartz, Mielck, 1998). Their production uses tableting technique, which is an attractive alternative to pellet production, as the presence of solvents is avoided and, due to the manufacturing process, defined sizes and strengths can be easily produced, with little variability within and between batches (Funaro et al., 2010). The advantages of multiparticulate systems can be associated with the advantages of modified drug release, enabling the achievement of systems that efficiently deliver the drug to its site of action.

Mesalamine is mainly used in the treatment of inflammatory bowel disease, such as ulcerative colitis and Crohn's disease, due to its local effect on intestinal and colonic mucosa and to its few side effects (Qureshi, Cohen, 2005). Mesalamine's mechanism of action is only partially understood, although it is accepted that its effect occurs locally in the intestinal mucosa by inhibiting cyclooxygenase and lipooxygenase, thus decreasing the production of prostaglandins and leukotrienes (Silva, 2006). In this way, the highest efficacy and least toxicity occur when the drug is specifically delivered to the affected area (Canevari et al., 2009).

The aim of this research was to develop a multiparticulate system with delayed and extended release formed by coated minitablets made of a hydrophilic matrix.
Mesalamine was used as model drug; the minitablets were made of hydrophilic polymer polyethylene-oxide and coated with a $\mathrm{pH}$-dependent metacrylic derived polymer. The drug release profile was evaluated and the release kinetics obtained.

\section{MATERIAL AND METHODS}

Pharmaceutical-grade raw materials were obtained from local suppliers and were used as received. The minitablets were prepared with anhydrous mesalamine (Deg Ltda, São Paulo, Brazil). The polyethylene oxide (Polyox ${ }^{\circledR}$ WSR 1105 , molecular weight $0.9 .10^{6}$ ) was kindly donated by Colorcon (Sao Paulo, Brazil). The other excipients were 200 microcrystalline cellulose (Microcel ${ }^{\circledR} 200$, Blanver Ltda, Sao Paulo, Brazil), magnesium stearate (Faci Spa, Carasco, Italy), and colloidal silicon dioxide (Blanver Ltda, São Paulo, Brazil). The coating was made via aqueous dispersion of the methacrylic-derived Eudragit ${ }^{\circledR}$ L30D55 (Degussa Ltda, Sao Paulo, Brazil).

\section{Preparation of the granules}

The selected technique for minitablet production was dry granulation. Formulations containing mesalamine, polyethylene oxide, magnesium stearate and colloidal silicon dioxide, as shown in Table I, were mixed in a plastic bag for $15 \mathrm{~min}$. The mixtures were compressed into $400 \mathrm{mg}$ slugs using an eccentric compression machine (EK0, ERweka GmbH, Heusenstamm, Germany) with a $13 \mathrm{~mm}$ planar punch. The slugs were crushed in a mortar and pestle and the granules were sieved on metal sifters (Bertel, Caieiras, Brazil) using 355, 500 and $710 \mu \mathrm{m}$ opening sieve mesh (42, 32 and 24 Tyler series sieve). Granules with a size fraction of 355-500 $\mu \mathrm{m}$ were withheld for powder flow analyses.

TABLE I - Composition of minitablet formulations

\begin{tabular}{|c|c|c|c|}
\hline Component & F1 (\%) & $\mathrm{F} 2(\%)$ & $\mathrm{F} 3(\%)$ \\
\hline Mesalamine & 40.0 & 40.0 & 40.0 \\
\hline Polyox ${ }^{\circledR}$ WSR 1105 & 20.0 & 30.0 & 40.0 \\
\hline $\begin{array}{l}\text { Mycrocrystalline cellulose } \\
200\end{array}$ & 38.0 & 28.0 & 18.0 \\
\hline Colloidal silicon dioxide & 0.5 & 0.5 & 0.5 \\
\hline Magnesium stearate & 1.5 & 1.5 & 1.5 \\
\hline
\end{tabular}




\section{Powder flow}

Determination of the static angle of repose was performed according to the method proposed by Prista, Alves, Morgado (1991) and Staniforth (2005) using the fixed-height funnel method (measuring the height and the radius of the cone formed when $30 \mathrm{~g}$ of the granule was allowed to flow gently trough the funnel). Bulk density was calculated from the volume of $10 \mathrm{~g}$ of granules occupying a $50 \mathrm{~mL}$ graduated cylinder, while for the tap density determination; the cylinder was tapped until no measurable change in volume was observed. The compressibility index and Hausner ratio were calculated based on bulk and tap density (Compressibility index = (tapped - bulk) x 100/tapped; Hausner ratio = tapped/ bulk) as described in the United States Pharmacopeia (USP 31, 2008). All powder flow analyses were made in triplicate.

\section{Production of minitablets}

The granules $(355-500 \mu \mathrm{m})$ were compressed using an eccentric compression machine (EK0, Erweka $\mathrm{GmbH}$, Heusenstamm, Germany) equipped with a triple planar punch $3 \mathrm{~mm}$ in diameter and manual feeding. A $500 \mathrm{~g}$ batch was prepared (for each formulation) and each minitablet weighed approximately $27 \mathrm{mg}$.

\section{Coating of minitablets}

The formulations, previously warmed to $40^{\circ} \mathrm{C}$, were coated in a fluidized bed (LM-FBD 5.0 Labmaq do Brasil Ltda, Ribeirao Preto, Brazil - inlet temperature of $40^{\circ} \mathrm{C}$ ) and a spray rate was $2.5 \mathrm{ml} . \mathrm{min}^{-1}$. After $10 \mathrm{~min}$, the spray rate was increased to $4.0 \mathrm{ml} \cdot \mathrm{min}^{-1}$. The coating solution (Eudragit ${ }^{\circledR}$ L-30D55, 10\% w/v) was applied until there was an $8 \%$ weight gain.

\section{Evaluation of the minitablets physical characteristics}

An evaluation of physical characteristics was performed for both uncoated and coated minitablets. The parameters evaluated were: weight variation, friability, diameter and thickness according to specifications of the Brazilian Pharmacopeia (2010).

\section{Drug content in minitablets}

The content of mesalamine in each batch (samples of $100 \mathrm{mg}$ ) was determined by ultraviolet spectroscopy
(UV-1601 UV-Visible Spectrophotometer Shimadzu) at $303 \mathrm{~nm}$ (Moharana et al., 2011).

\section{Coating level}

The level of coating was calculated by subtracting the content of mesalamine in coated minitablets from that found in uncoated minitablets (Amighi, Moes, 1996).

\section{Degree of swelling of tablets}

The degree of swelling $(\mathrm{H} \%)$ was investigated under conditions that simulated the gastrointestinal tract according to the methodology described by Moustafine et al. (2006).

\section{Dissolution profile}

Drug release from the formulations were evaluated on a Hanson ${ }^{\circledR}$ SR 6 dissolution tester (apparatus 2, $100 \mathrm{rpm}, 37^{\circ} \mathrm{C} \pm 0.5^{\circ} \mathrm{C}$ ) (Hanson Co., Chatsworth, USA) for twelve hours, divided into three stages ( $\mathrm{pH} 1.4$, 6.0 and 7.2) according to the methodology described by Chuong, Christensen and Ayres (2008). Samples of $5 \mathrm{~mL}$ were withdrawn (with replacement) at different times. The concentration of dissolved drug was measured by spectrophotometry (Shimadzu UV-1601, Kyoto, Japan) at a wavelength of $302 \mathrm{~nm}$ for the first stage, and $330 \mathrm{~nm}$ for the second and third stages. Sample quantification was based on previously constructed analytical curves (one for each $\mathrm{pH}$ ) and submitted to regression analysis. Linear relations were obtained in the concentration interval 5-100 $\mu \mathrm{g} \cdot \mathrm{mL}^{-1}$ with correlation coefficients (r) of 0.9998 (pH 1.4), 0.9997 (pH 6.0) and 0.9999 (pH 7.2).

The profiles obtained were compared using modelindependent and model-dependent methods. As a modelindependent method, the dissolution efficiency (DE\%) was calculated from the area under the dissolution curve at time $\mathrm{t}$ (measured using the trapezoidal rule) and expressed as a percentage of the rectangle described by $100 \%$ dissolution in the same time (Khan, 1975). The DE\% values were submitted to statistical comparison using analysis variance (ANOVA-single factor) in order to detect significant differences between the formulations, and then by Tukey's test. In the model-dependent approach, the release data were fitted to four kinetic models: zero-order, first-model, Higuchi model and Korsmeyer-Peppas model. The last model was calculated according to Equation 1 (Pillay, Fassihi, 1999):

$$
\frac{\mathrm{M}_{(\mathrm{t}-\mathrm{l})}}{\mathrm{M}_{\infty}}=\mathrm{K}_{\mathrm{k}}(\mathrm{t}-\mathrm{l})^{\mathrm{n}} \quad \text { Equation } 1
$$


where $\mathrm{t}-\mathrm{l}$ is the time excluding lag time, $\mathrm{M}_{(\mathrm{t}-1)}$ is the amount of drug dissolved in time t- $1, \mathrm{M}_{0}$ the initial amount of drug, $\mathrm{K}_{\mathrm{K}}$ the release constant and $n$, the release exponent, indicates the release mechanism (Peppas, 1985).

\section{RESULTS AND DISCUSSION}

The powder flow evaluation is one of the most important parameters in the development of a solid dosage form, because commercial production requires a continuous flow of powder mixes during the manufacturing process (Yang, Venkateshi, Fassihi, 1996). Because of the narrow diameter of the compression die used to obtain minitablets $(3 \mathrm{~mm})$, granules with excellent flow properties are required (Brabander et al., 2000). According to the literature, excellent flow properties are seen for powders with an angle of repose between $25^{\circ}$ and $30^{\circ}$, compressibility index below $10 \%$ and Hausner ratio below 1.11 (USP 31, 2008). All the formulations under evaluation had an angle of repose between $26^{\circ}$ and $29^{\circ}$, compressibility index less than $6 \%$ and Hausner ratio below 1.05 . Their excellent flow properties were also proved by the narrow weight distribution of the minitablets and their low friability, since all formulations had coefficient of variation values less than $5 \%$ relative to their mean weight and friability less than $1 \%$. These results demonstrated the suitability of all formulation mixtures used to produce minitablets.

The minitablets obtained also had suitable physical characteristics of thickness, diameter, and weight variation, with coefficient of variation values less than $5 \%(n=20)$.

Table II contains the results determined for mesalamine content in $100 \mathrm{mg}$ samples of the uncoated $(F 1, F 2$, and F3) and coated minitablets (F1R F2R and F3R). The content of the uncoated formulations was in agreement with the formulations (Table I) and was used as a reference for determining the coating level of F1R, F2R and F3R. As expected, there was a reduction in mesalamine content in the coated formulations, due to the level of coating applied. The values for the coating level $(\mathrm{mg} \%)$ for the formulations were in accordance with the planned weight gain (8\%).

The conditions of the coating process were chosen based on a previous study of Déo, Andreazza and Possamai (2011) that analysed mesalamine pellets coated with Eudragit $\AA$. The coating process was performed with a varying spray rate because, as the minitablets gain a coating, the adhesion of the film to the minitablets increases. Thus, the process started with a low spray rate that was increased over time, optimizing the processing time.

According to the Brazilian Pharmacopeia (2010), delayed release presents less than $10 \%$ of drug released at the end of the acid stage (120 min). This characteristic is seen in F2R and F3R, with a drug release of approximately $3.5 \%$ and $2.5 \%$, respectively, after $120 \mathrm{~min}$. The uncoated minitablets attained over $85 \%$ release in 120 minutes of testing, behaving as an immediate release dosage form. The F1R formulation had a drug release at the end of the acid release period of approximately $14 \%$, hence cannot be considered a delayed release formulation. This may occur because the F1R formulation had less Polyox ${ }^{\circledR}$, which implies fewer obstacles to release of the drug in the matrix.

The calculation of the release kinetics showed that the three formulations presented extended release, since the most suitable kinetic model was zero-order, as demonstrated in Table III. The zero-order kinetic model is considered the ideal model for extended release formulations, as pharmaceutical dosage forms following this profile release the same amount of drug per unit of time (Costa, Sousa Lobo, 2001). As the mechanism of mesalamine release from the matrix minitablet is not well-known, it was calculated using the KorsmeyerPeppas model, which relates drug release exponentially to the elapsed time. The magnitude of the exponent $n$ indicates the release mechanism. In the present study

TABLE II - Content of mesalamine and coating level

\begin{tabular}{lccc}
\hline & Content of mesalamine $(\mathrm{mg} \% *)$ & Coating level $(\mathrm{mg} \%)$ & Coating level $(\%)$ \\
\hline F1 & $38.70 \pm 0.53$ & - & - \\
F2 & $40.17 \pm 0.31$ & - & - \\
F3 & $39.64 \pm 1.33$ & - & - \\
F1R & $35.62 \pm 0.04$ & 3.08 & 7.96 \\
F2R & $36.88 \pm 0.05$ & 3.29 & 8.19 \\
F3R & $36.51 \pm 0.04$ & 3.13 & 7.89 \\
\hline
\end{tabular}

$*$ mean \pm coefficient of variation $(\mathrm{CV}) ; \mathrm{n}=3$ 


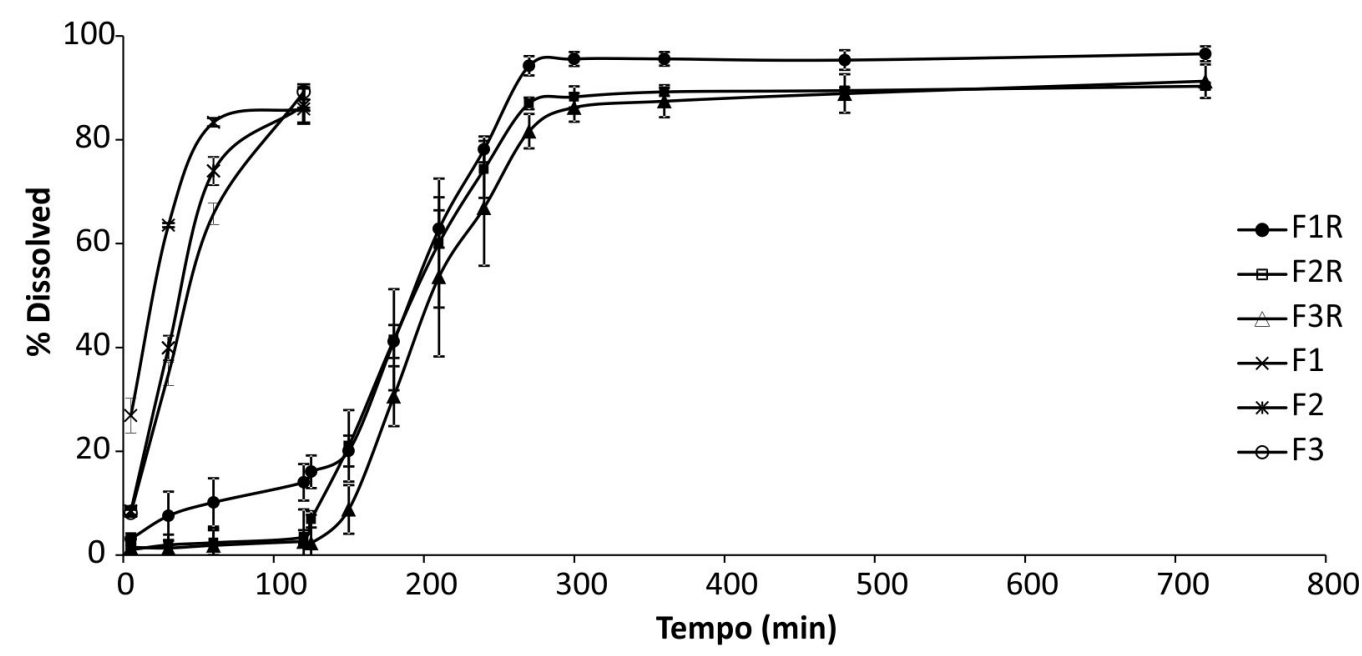

FIGURE 1 - Dissolution profiles of uncoated and coated formulations (mean $\pm \mathrm{SD} ; \mathrm{n}=6$ ).

TABLE III - Pearson's correlation coefficient (r), following linear dissolution data, and release exponent (n) (n=6)

\begin{tabular}{lccccc}
\hline \multirow{2}{*}{ Formulation } & Zero-order & First-order & \multicolumn{2}{c}{ Higuchi } & \multicolumn{2}{c}{ Korsmeyer-Peppas } \\
\cline { 2 - 6 } & $\mathrm{r}$ & $\mathrm{R}$ & $\mathrm{r}$ & $\mathrm{r}$ & $\mathrm{n}$ \\
\hline F1R & $\mathbf{0 . 9 7 6 7}$ & 0.9601 & 0.9685 & 0.9667 & 0.4623 \\
F2R & $\mathbf{0 . 9 9 9 5}$ & 0.9915 & 0.9982 & 0.9226 & 0.7637 \\
F3R & $\mathbf{0 . 9 9 1 3}$ & 0.9831 & 0.9881 & 0.9876 & 1.1121 \\
\hline
\end{tabular}

(cylindrical shape), the limits considered were $n=0.45$ (indicating a classical Fickian diffusion-controlled drug release), $n=0.89$ (case II transport), $0.45<n<0.89$ (anomalous transport) and $n>0.89$ (super case II transport).

The Korsmeyer-Peppas model showed that F1R and F2R presented anomalous transport and F3R a super case II transport (Table III). Anomalous transport indicates that the solvent diffusion rate and polymer relaxation occur are of the same order of magnitude, which means that the transport corresponds to coupled drug diffusion in the hydrated matrix and polymer relaxation. In super case II transport, the rate of solvent diffusion is greater and is the determining factor of the diffusion (Agnes, Ortega, 2003).

The results obtained for DE in percent (DE\%) are shown in Table IV. To infer the similarity between the formulations, the DE\% assessment entailed statistical analysis, performed between means, using ANOVA. Values of $F=17.6631$ (Fcritical $=3.1059)$ and $p$-value $=$ 3.65.10 $0^{-5}$ were obtained, which means the formulations are considered statistically different. Therefore, the means of treatment were compared using Tukey's test at $5 \%$ probability and it was found that F1R and F3R were statistically different.
TABLE IV - Dissolution efficiency of formulations F1R, F2R and F3R

\begin{tabular}{lc}
\hline Formulation & DE\%* \\
\hline F1R & $50.67 \pm 1.53$ \\
F2R & $48.33 \pm 0.57$ \\
F3R & $44.67 \pm 1.15$ \\
\hline
\end{tabular}

$*$ mean $\pm \mathrm{SD} ;(\mathrm{n}=6)$

Polyox ${ }^{\circledR}$ swelling occurs immediately upon hydration of the polymer. As the dry polymer becomes hydrated, the mobility of the polymer chains grows, increasing the hydrodynamic volume of the polymer compact, which allows the compact to swell. As polymer chains become more hydrated and the gel becomes more diluted, the disentanglement concentration may be reached, resulting in simultaneous swelling, dissolution, and erosion (Todd, L'Hote-Gaston, Sheick, 2008). The swelling behaviours of the three different kinds of minitablets are shown in Figure 2. The formulations show almost no increase in weight during the first $60 \mathrm{~min}$ due to the $\mathrm{pH}$ at this stage ( $\mathrm{pH} 1.4)$, since the minitablets are coated with a $\mathrm{pH}$-dependent polymer that dissolves at $\mathrm{pH}$ above 5.5. After $60 \mathrm{~min}$, the medium $\mathrm{pH}$ was increased 


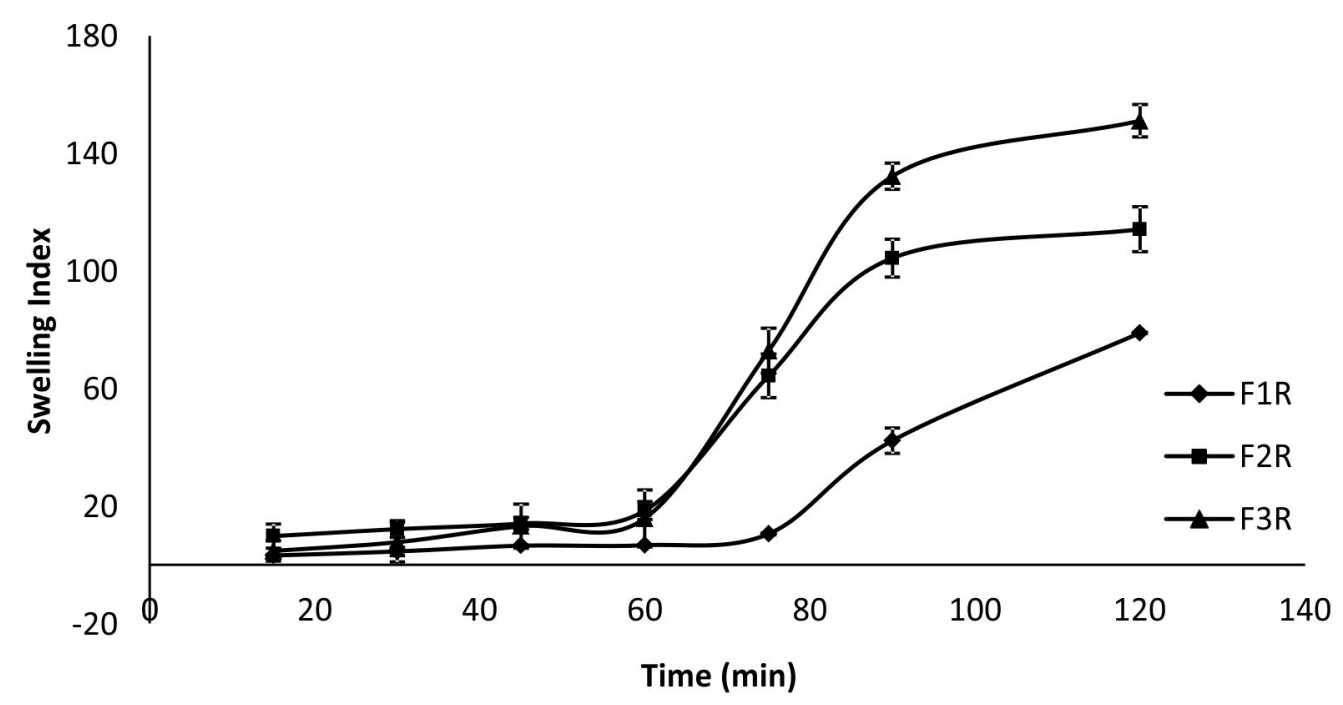

FIGURE 2 - Swelling index (mean $\pm \mathrm{SD}, \mathrm{n}=3$ ).

to 6.8 and the formulations presented increased weight (swelling), which was more pronounced in F3R. This characteristic was expected, since F3R has more Polyox ${ }^{\circledR}$ in its formulation and the polymer is hydrophilic.

After 120 minutes of testing, all the formulations presented a decrease in the degree of swelling, indicating the occurrence of erosion. This erosion process can be supported by the $n$ value found for the formulations (Table III). F1R and F2R presented an anomalous transport, indicating a joint action between the processes of swelling and erosion, as seen by Maggi et al. (2002) in a study using Polyox ${ }^{\circledR}$ WSR 1105 , in which it was suggested that the rate of swelling and erosion are similar and, therefore, both mechanisms are effective in controlling drug release. F3R presented super case II transport, which also indicates that drug release occurs by both swelling and erosion; however, the rate of water uptake occurs faster than polymer relaxation, promoting the erosion of the system (Steingraber, Schtoltz, Rodrigues, 2008). This characteristic may be a consequence of the greater amount of hydrophilic polymer, which has a high affinity for the dissolution tester medium.

It has been observed (Vendruscolo, 2005) that a higher proportion of polymer matrix reduces the rate of drug release, since a larger amount of polymer increases the degree of swelling, resulting in an increase in the drug diffusional path and consequent delay in the release rate. However, marked differences between the three formulations studied were not seen, suggesting that the prolongation of drug release in minitablets containing a large amount of drug in their composition is not greatly affected by variations in the amount of hydrophilic polymer used.

\section{CONCLUSION}

This study proposed the development of minitablets containing mesalamine with modified drug release: delayed release and extended release. The minitablets contained $20 \%, 30 \%$ or $40 \%$ Polyox ${ }^{\circledR}$ to sustain drug release and were coated with Eudragit ${ }^{\mathbb{R}}$ L30D55. The formulations with 30\% or $40 \%$ of the polymer presented delayed release and all formulations tested presented an extended release with zeroorder release kinetics. However, the dissolution profile was not greatly affected by the variations in the polymer used, and only the formulations with the lowest and the highest concentration of Polyox ${ }^{\circledR}$ were considered statistically different. The Korsmeyer-Peppas model suggested that both swelling and erosion mechanism influence drug release.

\section{ACKNOWLEDGMENTS}

The authors would like to thank the pharmaceutical company Colorcon ${ }^{\circledR}$ of Brazil for their support and supply of polymer, and the pharmaceutical company Prati $\&$ Donaduzzi for allowing the use of the equipment and facilities required to carry out the coating process.

\section{REFERENCES}

AGNES, E.J.; ORTEGA, G.G. Modelos matemáticos e físicoquímica da difusão. Cad. Farm., v.19, n.1, p.9-19, 2003.

ALLEN JR., L.V.; POPOVICH, N.G.; ANSEL, H.C. Ansel's pharmaceutical dosage forms and drug delivery systems. 8.ed. Philadelphia: Lippincott Williams \& Wilkins, 2005. $738 \mathrm{p}$. 
AMIGHI, K.; MÖES, A. Influence of plasticizer concentration and storage conditions on the drug release rate from eudragit ${ }^{\circledR}$ RS30D film-coated sustained-release teophylline pellets. Eur. J. Pharm. Biopharm., v.42, n.1, p.29-35, 1996.

BRABANDER, C.D.; VERVAET, C.; FIERMANS, L.; REMON, J.P. Matrix mini-tablets based on starch/ microcrystalline wax mixtures. Int. J. Pharm., v.199, n.2, p.195-203, 2000.

CANEVARI, M.; CASTAGLIUOLO, I.; BRUN, P.; CARDIN, M.; SCHIAVON, M.; PASUT, G.; VERONESE, F.M. Poly(ethylene glycol)-mesalazine conjugate for colon specific delivery. Int. J. Pharm., v.368, n.1-2, p.171-177, 2009.

CHUONG, M.C.; CHRISTENSEN, J.M.; AYRES, J.W. New dissolution method for mesalamine tablets and capsules. Dissolution Technol., v.15, n.3, p.7-14, 2008.

COSTA, P.; SOUSA LOBO, J.M. Modeling and comparison of dissolution profiles. Eur. J. Pharm. Sci., v.13, n.2, p.123$133,2001$.

DÉO, S.C.; ANDREAZZA, I.F.; POSSAMAI, J.C. Development of mesalazine pellets coated with methacrylicderived polymer. Braz. J. Pharm. Sci., v.47, n.1, p.103-109, 2011.

FARMACOPÉIA BRASILEIRA. 5.ed. São Paulo: Atheneu, 2010. p.66-73.

FUNARO, C.; MONDELLI, G.; PASSERINI, N.; ALBERTINI, B. Minitablets coated in a solid-wall pan for theophylline sustained-release capsules. Pharm. Technol., v.11, n.1, p.s38-s42, 2010.

GUPTA, V.K.; BECKERT, T.E.; PRICE, J.C. A novel pH- and time-based multi-unit potential colonic drug delivery system. I. Development. Int. J. Pharm., v.213, n.1, p.8391, 2001.

KHAN, K.A. The concept of dissolution efficiency. J. Pharm. Pharmacol., v.27, n.1, p.48-49, 1975.

KRAMAR, A.; TURK, S.; VRECER, F. Statistical optimization of diclofenac sodium sustained release pellets coated with polymethacrylic films. Int. J. Pharm., v.256, n.1-2, p.43$52,2003$.
LENNARTZ, P.; MIELCK, J.B. Minitabletting: improving the compactibility of paracetamol powder mixtures. Int. J. Pharm., v.173, n.1-2, p.75-85, 1998.

LOPES, C.M.; SOUSA LOBO, J.M.; PINTO, J.F.; COSTA, P. Compressed mini-tablets as a biphasic delivery system. Int. J. Pharm., v.323, n.1-2, p.93-100, 2006.

MAGGI, L.; SEGALE, L.; TORRE, M.L.; OCHOA MACHISTE, E.; CONTE, U. Dissolution behaviour of hydrophilic matrix tablets containing different polyethylene oxides (PEOs) for the controlled release water-soluble drug. Dimensionality study. Biomaterials, v.23, n.4, p.1113-1119, 2002.

MOHARANA, A.K.; BANERJEE, M.; PANDA, S.; MUDULI, J.N. Development and validation of UV spectrophotometric method for the determination of mesalazine in bulk and tablet formulation. Int. J. Pharm. Pharmacol., v.3, n.2, p.19-21, 2011.

MOUSTAFINE, R.I.; ZAHAROV, I.M.; KEMENOVA, V.A. Physicochemical characterization and drug release properties of Eudragit ${ }^{\circledR}$ E PO/Eudragit ${ }^{\circledR}$ L 100-55 interpolyelectrolyte complexes. Eur. J. Pharm. Biopharm., v.63, n.1, p.26-36, 2006.

NAGARAJU, R.; SWAPNA, Y.; BABU, R.H.; KAZA, R. Design and evaluation of delayed and extended release tablets of mesalamine. J. Pharm. Technol., v.2, n.1, p.103$110,2010$.

PEPPAS, N.A. Analysis of fickian and non-fickian drug release from polymers. Pharm. Acta Helv., v.60, n.4, p.100-111, 1985.

PILLAY, V.; FASSIHI, R. In vitro modulation from cross-linked pellets for site-specific drug delivery to the gastrointestinal tract. Part 1. Comparison of $\mathrm{pH}$-responsive drug release and associated kinetics. J. Controlled Release, v.59, n.20, p.229-242, 1999.

PRISTA, L.V.N.; ALVES, A.C.; MORGADO, R.M.R. Técnica farmacêutica e farmácia galénica. 4.ed. Lisboa: Fundação Calouste Gulbenkian, 1991. v.1, p.591-799.

QURESHI, A.I.; COHEN, R.D. Mesalamine delivery systems: do they really make much difference? Adv. Drug Deliver. Rev., v.57, n.2, p.281-302, 2005. 
STANIFORTH, J.N. Fluxo de pós. In: AULTON, M.E. (Ed.). Delineamento de formas farmacêuticas. 2.ed. Porto Alegre: Artmed, 2005. p.208-221.

SILVA, P. Farmacologia. 7.ed. Rio de Janeiro: Guanabara Koogan, 2006. p.896-899.

STEINGRABER, T.; SCHTOLTZ, T.; RODRIGUES, P.O. Avaliação da influência de adjuvantes não-poliméricos solúveis na liberação do nimodipino a partir de formulações matriciais de liberação prolongada. Rev. Colomb. Ciênc. Quim. Farm., v.37, n.2, p.122-132, 2008.

TODD, P.G.; L'HOTE-GASTON, J.; SHEICK, M. Comparison of swelling, erosion, and gel strength og polyethylene oxide and hypromellose. Annual Meeting and Exposition of the American Association of Pharmaceutical Scientists, 2008. 1 cartaz, color.
UNITED STATES PHARMACOPEIA. 31.ed. Rockville: United States Pharmacopeial Convention, 2008. p.26292632.

VENDRUSCOLO, C.W. Goma xantana e galactomanana (M. scabrella): desenvolvimento matrizes hidrofílicas para liberação modificada de teofilina. Itajaí, 2005. 111 p. [Dissertion of master degree. Education Center for Health Sciences. University of Vale do Itajaí].

YANG, L.; VENKATESHI, G.; FASSIHI, R. Characterization of compressibility and compactibility of poly(ethylene oxide) polymers for modified release application by compaction simulator. J. Pharm. Sci., v.85, n.10, p.1085-1090, 1996.

Received for publication on $03^{\text {rd }}$ August 2012

Accepted for publication on $15^{\text {th }}$ May 2013 